\author{
V.V. Romanuke \\ Polish Naval Academy, Gdynia, Poland
}

\title{
ACYCLIC-AND-ASYMMETRIC PAYOFF TRIPLET REFINEMENT OF PURE STRATEGY EFFICIENT NASH EQUILIBRIA IN TRIMATRIX GAMES BY MAXIMINIMIN AND SUPEROPTIMALITY
}

\begin{abstract}
Background. A problem of selecting amongst efficient Nash equilibria is solved by refining them. The existing approaches to refining do not guarantee that the refined efficient Nash equilibrium will be single. Nevertheless, a novel approach to refining pure strategy efficient Nash equilibria in bimatrix games suggested before exploits the maximin and superoptimality rule that, at least partially, remove the uncertainty of the equilibria.

Objective. The goal of the article is to develop the bimatrix game approach expanding it over trimatrix games for refining efficient Nash equilibria as much further as possible.

Methods. An efficient Nash equilibria refinement is suggested for trimatrix games, which is based on expanding the refinement approach for bimatrix games, exploiting the maximinimin and superoptimality. Games with acyclic-andasymmetric payoff triplets are only considered.

Results. Series of trimatrix game simulations allow concluding on that whereas the refinement is needed in about between $33 \%$ and $65 \%$ of trimatrix games where players possess between 4 to 12 pure strategies (this rate increases as the game size increases), it is perfectly accomplished to a single metaequilibrium in roughly between $46 \%$ and $52 \%$ of those cases (this rate decreases as the game size increases), using maximinimin only, without the superoptimality rule. Exploiting the maximin, expanded to the maximinimin principle, and superoptimality using now doublesumming, the main work for the refinement is off the maximinimin principle.

Conclusions. An algorithm for the developed approach refinement in trimatrix games is very simple. It consists of four generalized items. Although a total fail of the refinement is not excluded, the aggregate efficiency of removing the uncertainty of equilibria by the maximinimin principle and superoptimality rule seems satisfactory.
\end{abstract}

Keywords: trimatrix game; efficient Nash equilibria; refinement; maximinimin; superoptimality rule.

\section{Introduction}

Efficient Nash equilibria seeming a certain output of game models result in another decisionmaking problem. Such a decision-making problem is solved by refining the equilibria [1, 2]. The refinement implies selecting the best efficient Nash equilibria, if not going into $\varepsilon$-equilibria and the likes $[3,4]$. In a wider sense, the refinement implies narrowing down the solutions (whereas efficient Nash equilibria are a particular example of a set of the game model solutions) [1, 5, 6].

The existing approaches to refining do not guarantee that the refined efficient Nash equilibrium will be single $[1,2,6,7]$. And sometimes efficient Nash equilibria are nonrefinable because of lack of an additional information that could have helped in distinguishing among efficient Nash equilibria $[8,9]$. Simple examples of the nonrefinability are easily shown with bimatrix games, wherein efficient Nash equilibria produce identical/symmetric payoffs [7].

Trimatrix games modeling trilateral interactions have a little bit harder decision-making prob- lems on the refinement. It is clearly explained with that efficient Nash equilibria in a trimatrix game produce payoff triplets, and thus distinguishing among such triplets becomes more sophisticated. Meanwhile, trimatrix game models have a wider applicability than that of bimatrix games [10, 11].

A novel approach to refining pure strategy efficient Nash equilibria in bimatrix games was suggested in article [7]. It exploits the maximin rule aiming at guaranteeing payoffs. The superoptimality rule $[12,13]$ is involved if maximin fails to produce just a single refined efficient Nash equilibrium. Without going into mixed strategies, that bimatrix game approach partially removes/reduces the uncertainty of efficient Nash equilibria. But there are two negative cases when the refinement fails.

\section{Problem statement}

The goal of the article is to develop the bimatrix game approach expanding it over trimatrix games for refining efficient Nash equilibria as much further as possible. For achieving the goal, the eight tasks are to be accomplished:

\footnotetext{
* corresponding author: romanukevadimv@gmail.com
} 
1. To state denotations of trimatrix game and its efficient Nash equilibria that are going to be refined.

2. To circumscribe properties of payoff matrices, which are to be considered only for the refinement.

3. To circumscribe properties of efficient Nash equilibria, which are only possible to be refined for the trimatrix games whose payoff matrices have the before-circumscribed properties.

4. To append the maximin principle and superoptimality rule for selecting amongst nonrefinable efficient Nash equilibria in trimatrix games.

5. To describe the reasonability that will answer a question of why players should noncooperatively come at the best efficient Nash equilibrium returned by the developed approach refinement.

6. To draw a generalized scheme of an algorithm of using the developed approach refinement in trimatrix games.

7. To show illustratively how the algorithm works on real-valued examples of trimatrix games having efficient Nash equilibria, which are nonrefinable by the known concepts [1, 2, 5, 7, 14, 15].

8. To discuss the developed approach and its algorithm, and emphasize some unsolved issues, if any, in them [7].

The said task of showing illustratively the algorithm's work is aimed at understanding the process of refinement better. Advantages of selected/refined Nash equilibria should be seen clearly. Disadvantages and issues ought to be explained as well.

\section{Denotations of trimatrix game and its efficient Nash equilibria}

We consider a trimatrix game with real-valued $M \times N \times K$ payoff matrices

$$
\begin{gathered}
\mathbf{A}=\left(a_{m n k}\right)_{M \times N \times K} \text { and } \\
\mathbf{B}=\left(b_{m n k}\right)_{M \times N \times K} \text { and } \\
\mathbf{C}=\left(c_{m n k}\right)_{M \times N \times K}
\end{gathered}
$$

of the first, second, and third players, whose sets of pure strategies are $X=\left\{x_{m}\right\}_{m=1}^{M}, \quad Y=\left\{y_{n}\right\}_{n=1}^{N}, \quad Z=$ $=\left\{z_{k}\right\}_{k=1}^{K}, \quad M \in \mathbb{N} \backslash\{1\}, N \in \mathbb{N} \backslash\{1\}, K \in \mathbb{N} \backslash\{1\}$, respectively. The game is assumed to be non-repeatable. Set $E=\left\{e_{q}\right\}_{q=1}^{Q}$ is assumed to be a set of pure strategy efficient Nash equilibria in trimatrix game with payoff matrices (1), where $Q \in \mathbb{N} \backslash\{1\}$ (having a case $Q=1$ makes a refinement needless):

$$
\begin{gathered}
e_{q}=\left\{x_{q}^{*}, y_{q}^{*}, z_{q}^{*}\right\} \\
\text { by } x_{q}^{*} \in X \\
\text { and } y_{q}^{*} \in Y \\
\text { and } z_{q}^{*} \in Z .
\end{gathered}
$$

Pure strategy efficient Nash equilibrium (2) produces a payoff triplet

$$
\left\{a_{q}^{*}, b_{q}^{*}, c_{q}^{*}\right\}
$$

whose elements are the respective elements of payoff matrices (1). Nash equilibria, which are not efficient, bear no utility, and thus they are not specified intentionally $[1,2,7,11,16,17]$.

The set of all pure strategy efficient Nash equilibria in trimatrix game with payoff matrices (1) is a subset of all pure strategy situations containing equilibrium strategies of every player:

$$
E=\left\{e_{q}\right\}_{q=1}^{Q} \subset X_{*} \times Y_{*} \times Z_{*} \subset X \times Y \times Z
$$

by

$$
\begin{gathered}
X_{*}=\left\{x_{m_{*}}\right\}_{m_{*} \in \mathscr{M} *} \subset X \text { and } \\
Y_{*}=\left\{y_{n_{*}}\right\}_{n_{*} \in \mathscr{C O N}_{*}} \subset Y \text { and } \\
Z_{*}=\left\{z_{k_{*}}\right\}_{k_{*} \in \mathscr{K _ { * }}} \subset Z,
\end{gathered}
$$

where the indices' subsets

$$
\begin{gathered}
\mathscr{M}_{*} \subset\{\overline{1, M}\} \text { and } \\
\mathscr{N}_{*} \subset\{\overline{1, N}\} \text { and } \\
\mathscr{K}_{*} \subset\{\overline{1, K}\}
\end{gathered}
$$

are such that for every element of set $X_{*}$ $\exists q \in\{\overline{1, Q}\}$ such that $x_{m_{*}} \in e_{q}$, for every element of set $Y_{*} \quad \exists q \in\{\overline{1, Q}\}$ such that $y_{n_{*}} \in e_{q}$, and for every element of set $Z_{*} \exists q \in\{\overline{1, Q}\}$ such that $z_{k_{*}} \in e_{q}$. Note that every element of set $X_{*} \times Y_{*} \times Z_{*}$ is not necessarily an equilibrium point, i. e. some triplets $\left\{x_{m_{*}}, y_{n_{*}}, z_{k_{*}}\right\} \in$ $\in X_{*} \times Y_{*} \times Z_{*}$ may not be the equilibria (see Fig. 1 and also refer to Fig. 1 in [7]). 


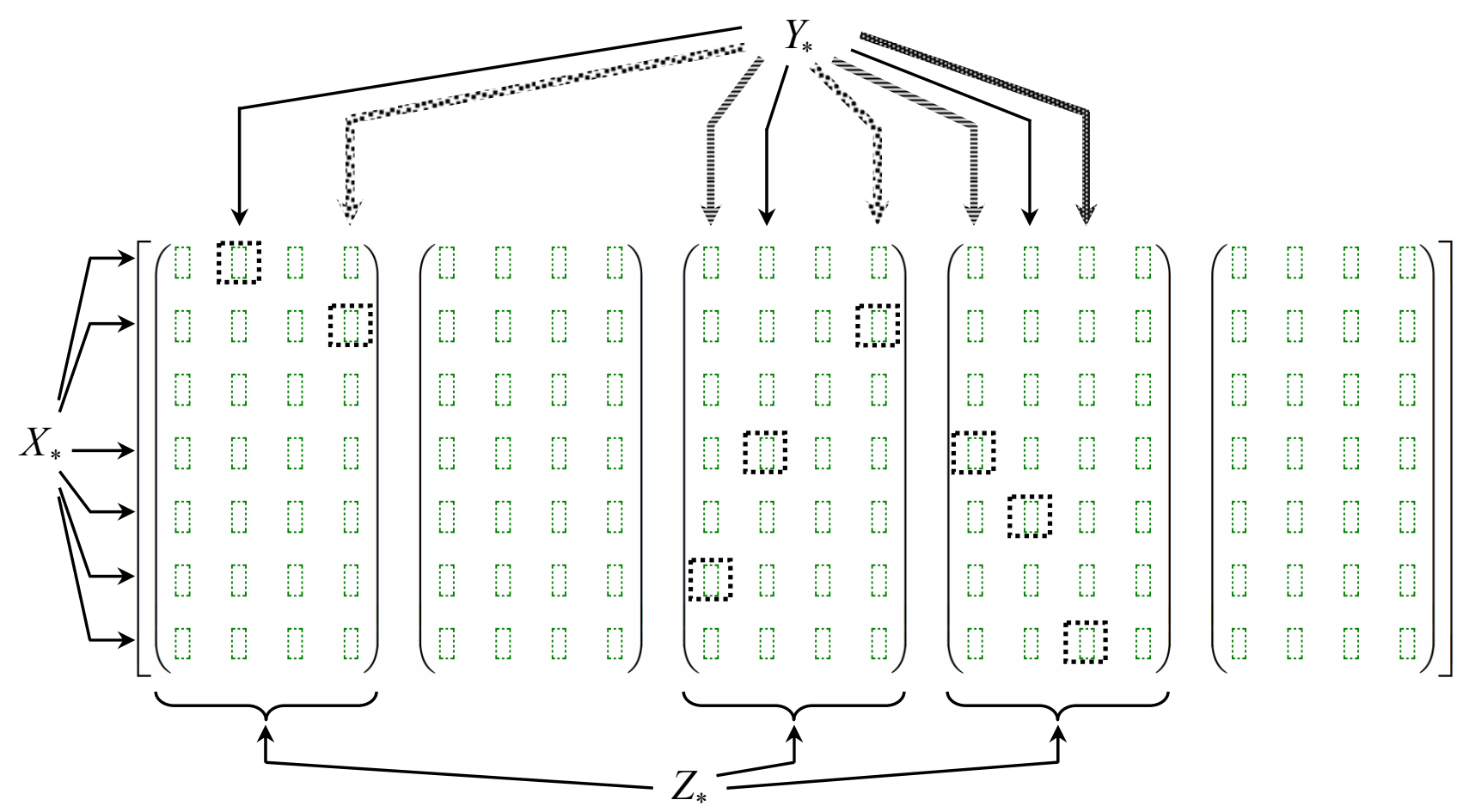

Fig. 1. An example sketch of the efficient Nash equilibria set (highlighted via dashed rectangles) and its relation to subsets (5) over a player's payoff three-dimensional matrix of size $7 \times 4 \times 5$ (refer also to a similar bimatrix game example in [7])

It is worth to remember that set $E=\left\{e_{q}\right\}_{q=1}^{Q}$ contains only those situations that are not dominated, strictly and non-strictly. If a situation is dominated non-strictly then it is not an efficient Nash equilibrium. For trimatrix games, it means that a situation producing payoffs (without losing generality)

$$
\left\{a_{q}^{*}-\varepsilon, b_{q}^{*}, c_{q}^{*}\right\} \quad \forall \varepsilon>0
$$

cannot be an efficient Nash equilibrium, whichever situation producing payoffs (3) is. If we implied the weak Pareto efficiency for the efficient Nash equilibria, then both situations producing payoffs (3) and (7) would be efficient, if the first situation was known as an efficient Nash equilibrium. With the weak efficiency, additionally to the said, we would have a situation producing payoffs (again, without losing generality)

$$
\left\{a_{q}^{*}-\varepsilon, b_{q}^{*}-\delta, c_{q}^{*}\right\} \quad \forall \varepsilon>0 \text { and } \forall \delta>0
$$

efficient as well [16, 18, 19]. Weak efficient Nash equilibria are fairly senseless in bimatrix games, and are fairly senseless in those trimatrix games, where the situation producing payoffs (3) is an efficient equilibrium and we deal with the situation producing payoffs (8) by pretty great $\varepsilon$ and $\delta$. Weak efficiency of Nash equilibria is not so sense- less for trimatrix games with weak efficient Nash equilibria producing payoffs (3) and (7) by pretty small $\varepsilon[10,11,16,20,21]$.

\section{Properties of payoff matrices (1) to be consid- ered for the refinement}

Matrices (1) cannot be null matrices. Generally, none of those three matrices can have elements, whose values are the same. They also do not contain strictly dominated two-dimensional slices. For example, instead of $3 \times 2 \times 2$ matrices

$$
\begin{aligned}
& \mathbf{A}=\left[\left(\begin{array}{ll}
7 & 4 \\
5 & 5 \\
6 & 3
\end{array}\right)\left(\begin{array}{ll}
6 & 2 \\
0 & 4 \\
5 & 0
\end{array}\right)\right], \\
& \mathbf{B}=\left[\left(\begin{array}{ll}
7 & 6 \\
7 & 6 \\
2 & 1
\end{array}\right)\left(\begin{array}{ll}
1 & 3 \\
4 & 5 \\
9 & 2
\end{array}\right)\right], \\
& \mathbf{C}=\left[\left(\begin{array}{ll}
7 & 6 \\
2 & 8 \\
5 & 9
\end{array}\right)\left(\begin{array}{ll}
5 & 2 \\
1 & 8 \\
1 & 2
\end{array}\right)\right],
\end{aligned}
$$


we should consider a trimatrix game with payoff $2 \times 2 \times 2$ matrices $[11,15,22]$

$$
\begin{aligned}
& \mathbf{A}=\left[\left(\begin{array}{ll}
7 & 4 \\
5 & 5
\end{array}\right)\left(\begin{array}{ll}
6 & 2 \\
0 & 4
\end{array}\right)\right], \\
& \mathbf{B}=\left[\left(\begin{array}{ll}
7 & 6 \\
7 & 6
\end{array}\right)\left(\begin{array}{ll}
1 & 3 \\
4 & 5
\end{array}\right)\right], \\
& \mathbf{C}=\left[\left(\begin{array}{ll}
7 & 6 \\
2 & 8
\end{array}\right)\left(\begin{array}{ll}
5 & 2 \\
1 & 8
\end{array}\right)\right],
\end{aligned}
$$

because the third slice of matrix $\mathbf{A}$ in (9) is strictly dominated by its first slice (slicing vertically). Then the $3 \times 2 \times 2$ game is reduced to the $2 \times 2 \times 2$ game as the first player will not ever use one's strictly dominated strategy. Note that the trimatrix game with payoff matrices (10) has two efficient Nash equilibria $-e_{1}=\left\{x_{1}, y_{1}, z_{1}\right\}$ and $e_{2}=\left\{x_{2}, y_{2}, z_{2}\right\}$ producing the respective payoffs $\{7,7,7\}$ and $\{4,5,8\}$. Meanwhile, payoffs $\{4,5,8\}$ are produced by the situation that belongs to the non-strictly dominated second slice of matrix $\mathbf{C}$ (slicing in depth, where the left flat submatrix non-strictly dominates the right flat submatrix).

\section{Properties of efficient Nash equilibria, which are only possible to be refined}

Let matrix A have elements whose values are only $\alpha_{0}$ and $\alpha$, and let matrix $\mathbf{B}$ have elements whose values are only $\beta_{0}$ and $\beta$, and let matrix $\mathbf{C}$ have elements whose values are only $\gamma_{0}$ and $\gamma$. If matrices

$$
\mathbf{A}-\alpha_{0} \text { and } \mathbf{B}-\beta_{0} \text { and } \mathbf{C}-\gamma_{0}
$$

are of diagonal/antidiagonal $M \times N$ matrices in each of their third-dimension's slices, then, whichever values

$$
\left[\begin{array}{lll}
\alpha_{0} & \beta_{0} & \gamma_{0}
\end{array}\right] \in \mathbb{R}^{3}
$$

are, efficient Nash equilibria, which are only possible to be refined, must produce anything but payoffs

$$
\begin{gathered}
\left\{a_{q}^{*}, b_{q}^{*}, c_{q}^{*}\right\}=\{\alpha, \beta, \gamma\} \\
\text { by }\left[\begin{array}{ccc}
\alpha & \beta & \gamma
\end{array}\right] \in \mathbb{R}^{3} \\
\forall q=\overline{1, Q}
\end{gathered}
$$

because those payoff-identical equilibria may be absolutely non-distinguishable. For instance, a trimatrix $2 \times 2 \times 2$ game with payoffs matrices

$$
\begin{aligned}
\mathbf{A} & =\left[\left(\begin{array}{cc}
\alpha & \alpha_{0} \\
\alpha_{0} & \alpha
\end{array}\right)\left(\begin{array}{cc}
\alpha & \alpha_{0} \\
\alpha_{0} & \alpha
\end{array}\right)\right] \text { and } \\
\mathbf{B} & =\left[\left(\begin{array}{cc}
\beta & \beta_{0} \\
\beta_{0} & \beta
\end{array}\right)\left(\begin{array}{cc}
\beta & \beta_{0} \\
\beta_{0} & \beta
\end{array}\right)\right] \text { and } \\
\mathbf{C} & =\left[\left(\begin{array}{ll}
\gamma & \gamma_{0} \\
\gamma_{0} & \gamma_{0}
\end{array}\right)\left(\begin{array}{ll}
\gamma_{0} & \gamma_{0} \\
\gamma_{0} & \gamma
\end{array}\right)\right]
\end{aligned}
$$$$
\text { by } \alpha>\alpha_{0}, \beta>\beta_{0}, \gamma>\gamma_{0}
$$

has two efficient Nash equilibria producing identical payoff triplets $\{\alpha, \beta, \gamma\}$. It is clear that they are absolutely non-distinguishable here (we will understand a rigorous proof later). Note that the slices (left and right ones) of matrix $\mathbf{C}$ are different, unlike the slices of matrices $\mathbf{A}$ and $\mathbf{B}$. Obviously, if matrices (11) are not of square $M \times N$ matrices in each of their third-dimension's slices, but these slices are semi-diagonal/semi-antidiagonal matrices with additional constant rows/columns, then the same condition holds - the produced payoffs (12) are non-distinguishable. As a simple appendix to the trimatrix game with payoffs matrices (13), this could be a trimatrix $3 \times 2 \times 2$ game with payoffs matrices

$$
\begin{aligned}
\mathbf{A} & =\left[\left(\begin{array}{ll}
\alpha_{0} & \alpha \\
\alpha_{0} & \alpha_{0} \\
\alpha & \alpha_{0}
\end{array}\right)\left(\begin{array}{ll}
\alpha_{0} & \alpha \\
\alpha_{0} & \alpha_{0} \\
\alpha & \alpha_{0}
\end{array}\right)\right] \text { and } \\
\mathbf{B} & =\left[\left(\begin{array}{ll}
\beta_{0} & \beta \\
\beta_{0} & \beta_{0} \\
\beta & \beta_{0}
\end{array}\right)\left(\begin{array}{ll}
\beta_{0} & \beta \\
\beta_{0} & \beta_{0} \\
\beta & \beta_{0}
\end{array}\right)\right] \text { and } \\
\mathbf{C} & =\left[\left(\begin{array}{ll}
\gamma_{0} & \gamma \\
\gamma_{0} & \gamma_{0} \\
\gamma_{0} & \gamma_{0}
\end{array}\right)\left(\begin{array}{ll}
\gamma_{0} & \gamma_{0} \\
\gamma_{0} & \gamma_{0} \\
\gamma & \gamma_{0}
\end{array}\right)\right]
\end{aligned}
$$$$
\text { by } \alpha>\alpha_{0}, \beta>\beta_{0}, \gamma>\gamma_{0} \text {, }
$$

wherein the said identical payoff triplets are still non-distinguishable (e. g., see [8, 11, 23, 24]). 


\section{Maximin principle and superoptimality rule for selecting amongst nonrefinable efficient Nash equilibria in trimatrix games}

Once the efficient Nash equilibria are found, a reduced trimatrix game defined on product $X_{*} \times Y_{*} \times Z_{*}$ is built. In such a game, payoff matrices are

$$
\begin{gathered}
\mathbf{A}_{*}=\left(a_{m_{1} n_{1} k_{1}}^{*}\right)_{M_{*} \times N_{*} \times K_{*}} \text { and } \\
\mathbf{B}_{*}=\left(b_{m_{1} n_{1} k_{1}}^{*}\right)_{M_{*} \times N_{*} \times K_{*}} \text { and } \\
\mathbf{C}_{*}=\left(c_{m_{1} n_{1} k_{1}}^{*}\right)_{M_{*} \times N_{*} \times K_{*}}
\end{gathered}
$$

where

$$
\begin{gathered}
M_{*}=\left|e \mathscr{M}_{*}\right|=\left|X_{*}\right|, N_{*}=\left|\mathscr{C N}_{*}\right|=\left|Y_{*}\right|, \\
K_{*}=\left|\varrho \mathcal{K}_{*}\right|=\left|Z_{*}\right|, \\
a_{m_{1} n_{1} k_{1}}^{*}=a_{m_{*} n_{*} k_{*}}, b_{m_{1} n_{1} k_{1}}^{*}=b_{m_{*} n_{*} k_{*}}, c_{m_{1} n_{1} k_{1}}^{*}=c_{m_{*} n_{*} k_{*}}
\end{gathered}
$$

by re-indexing with

$$
\begin{gathered}
m_{1}=\overline{1, M_{*}} \text { and } m_{*} \in \mathscr{M}_{*}, \quad n_{1}=\overline{1, N_{*}} \text { and } \\
n_{*} \in \mathscr{N}_{*}, \quad k_{1}=\overline{1, K_{*}} \text { and } k_{*} \in \mathscr{C}_{*} .
\end{gathered}
$$

If matrices (15), being the corresponding submatrices of matrices (1), become flat, then one of the players has already a single strategy belonging to all of those $Q$ efficient equilibria. If matrices (15) are not flat, then they constitute the reduced trimatrix $M_{*} \times N_{*} \times K_{*}$ game, and the uncertainty amongst the equilibria still is the same as it is for the initial game.

To remove the uncertainty, the maximin principle can be applied guaranteeing the corresponding payoffs for the players. For trimatrix $M_{*} \times N_{*} \times K_{*}$ games, this principle is the maximinimin $[25,26]$ :

$$
\begin{aligned}
& X_{* *}=\left\{x_{m_{* *}}\right\}_{m_{* *} \in \mathscr{C}} \\
& =\arg \max _{\substack{X_{m_{*}} \\
m_{*} \in \mathscr{M} \mathscr{M}_{*}}} \min _{n_{*} \in \mathscr{C}_{*}} \min _{k_{*} \in \mathscr{K _ { * }}} a_{m_{*} n_{*} k_{*}} \subset X_{*} \subset X \\
& \text { by } \mathscr{M}_{* *} \subset \mathscr{M}_{*} \text {, } \\
& Y_{* *}=\left\{y_{n_{* *}}\right\}_{n_{* *} \in \mathscr{C N}_{* *}} \\
& =\arg \max _{\substack{y_{n_{*}} \\
n_{*} \in \mathscr{V}_{*}}} \min _{m_{*} \in \mathscr{C} \mathscr{H}_{*}} \min _{k_{*} \in \mathscr{C}_{*}} b_{m_{*} n_{*} k_{*}} \subset Y_{*} \subset Y \\
& \text { by } \mathscr{N}_{* *} \subset \mathscr{N}_{*} \text {, }
\end{aligned}
$$

$$
\begin{gathered}
Z_{* *}=\left\{z_{k_{* *}}\right\}_{k_{* *} \in \mathscr{K} \mathscr{K}_{* *}} \\
=\arg \max _{\substack{Z_{k_{*}} \\
k_{*} \in \mathscr{C} \mathscr{K}_{*}}} \min _{m_{*} \in \mathscr{M}_{*}} \min _{n_{*} \in \mathscr{C} \mathscr{N}_{*}} c_{m * n_{*} k_{*}} \subset Z_{*} \subset Z
\end{gathered}
$$

by $\mathscr{K}_{* *} \subset \mathscr{K}_{*}$,

whereupon the first, second, and third players are guaranteed to get payoffs not less than

$$
\begin{aligned}
& a_{* *}=\max _{m_{*} \in \mathscr{C} \mathscr{M}_{*}} \min _{n_{*} \in \mathscr{C}_{*}} \min _{k_{*} \in \mathscr{C}_{*}} a_{m_{*} n_{*} k_{*}}, \\
& b_{* *}=\max _{n_{*} \in \mathscr{C} \mathscr{N}_{*}} \min _{m_{*} \in \mathscr{C} \mathscr{M}_{*}} \min _{k_{*} \in \mathscr{K} \mathscr{K}_{*}} b_{m_{*} n_{*} k_{*}}, \\
& \mathcal{C}_{* *}=\max _{k_{*} \in \mathscr{O} \mathscr{K}_{*}} \min _{m_{*} \in \mathscr{M} \mathscr{M}_{*} \in \min _{*} \in \mathscr{V}_{*}} c_{m_{*} n_{*} k_{*}},
\end{aligned}
$$

respectively. Note that, however, not all situations in the set

$$
L=X_{* *} \times Y_{* *} \times Z_{* *}
$$

are efficient Nash equilibria. Moreover, set (22) may not contain any equilibria.

If set

$$
R=L \cap E=\left\{X_{* *} \times Y_{* *} \times Z_{* *}\right\} \cap\left\{e_{q}\right\}_{q=1}^{Q}
$$

is nonempty then it contains the refined efficient Nash equilibria. In particular, if set (23) contains just a single element, then the refinement is done as it is the single efficient Nash equilibrium. If $R=\varnothing$ or $|R|>1$ then the superoptimality rule originally introduced for distinguishing optimal strategies in matrix games (see $[12,13,27])$ can be applied just as well as it is applied for bimatrix games in [7].

If set $R=\varnothing$ then using strategies from subsets (16), (17), and (18) involves players into nonstability provoking them to search new pure strategies beyond these subsets for every game round (as there is no a single equilibrium point). In such a case, one of the best actions is to use strategies from subsets

$$
\begin{aligned}
& \hat{X}_{*}=\left\{x_{\hat{m}_{*}}\right\}_{\hat{m}_{*} \in \mathscr{M}} \\
& =\arg \max _{\substack{X_{m_{*}} \\
m_{*} \in \mathscr{C M}_{*}}} \sum_{n_{*} \in \mathscr{C}_{*} \boldsymbol{N}_{*} \in \mathscr{C}_{*}} \sum_{\mathscr{m}_{*} n_{*} k_{*}} \subset X_{*} \subset X \\
& \text { by } \mathscr{M}_{*}^{*} \subset \mathscr{M}_{*} \text {, } \\
& \widehat{Y}_{*}=\left\{y_{\hat{n}_{*}}\right\}_{\hat{n}_{*} \in \mathcal{C N}}{ }_{*}^{*} \\
& =\arg \max _{\substack{y_{n_{*}} \\
n_{*} \in \mathscr{C}_{*}}} \sum_{m_{*} \in \mathscr{M}_{*}} \sum_{k_{*} \in \mathscr{C} \mathscr{K}_{*}} b_{m_{*} n_{*} k_{*}} \subset Y_{*} \subset Y
\end{aligned}
$$$$
\text { by } \mathscr{N}_{*}^{*} \subset \mathscr{N}_{*},
$$ 


$$
\begin{gathered}
\hat{Z}_{*}=\left\{z_{\widehat{k}_{*}}\right\}_{\widehat{k}_{*} \in \mathscr{C}_{*}^{*}} \\
=\arg \max _{\substack{Z_{k_{*}} \\
k_{*} \in \mathscr{C}_{*}}} \sum_{m_{*} \in \mathscr{M}_{*}} \sum_{n_{*} \in \mathscr{C}_{*}} c_{m_{*} n_{*} k_{*}} \subset Z_{*} \subset Z
\end{gathered}
$$

by $\mathscr{K}_{*}^{*} \subset \mathscr{e} \mathcal{K}_{*}$,

that guarantee for players their best payoffs under uncertainty of the efficient equilibria. This uncertainty reduction concerns as the trimatrix game with payoff matrices (1), as well as the reduced game with payoff matrices (15), whether matrices (15) are flat or not.

In the case of $|R|>1$ we still have an uncertainty of that which equilibrium to be selected, as there are at least two equilibria in product (22) of maximinimin subsets (16), (17), and (18). Let

$$
R \subset X_{R} \times Y_{R} \times Z_{R}
$$

by

$$
\begin{gathered}
\left\{x^{\langle R\rangle}, y^{\langle R\rangle}, z^{\langle R\rangle}\right\} \in R, \quad x^{\langle R\rangle} \in X_{R}, \\
y^{\langle R\rangle} \in Y_{R}, \quad z^{\langle R\rangle} \in Z_{R},
\end{gathered}
$$

and the respective indices' subsets

$$
\begin{aligned}
& \mathscr{M}_{* *}^{\langle R\rangle} \subset \mathscr{M}_{* *} \subset \mathscr{M}_{*}, \\
& \mathscr{N}_{* *}^{\langle R\rangle} \subset \mathscr{N}_{* *} \subset \mathscr{N} \mathscr{N}_{*}, \\
& \mathscr{K}_{* *}^{\langle R\rangle} \subset \mathscr{K}_{* *} \subset \mathscr{C K}_{*},
\end{aligned}
$$

by which

$$
\begin{aligned}
& X_{R}=\left\{x_{m_{* *}^{\langle R\rangle}}\right\}_{m_{* *}^{\langle R\rangle} \in \mathscr{C} \mathscr{M}_{* *}^{\langle R\rangle}}, \\
& Y_{R}=\left\{y_{n_{* *}^{\langle R\rangle}}\right\}_{n_{* *}^{\langle R\rangle} \in \mathcal{O} \mathscr{N}_{* *}^{\langle R\rangle}}, \\
& Z_{R}=\left\{z_{k_{* *}^{\langle R\rangle}}\right\}_{k_{* *}^{\langle R\rangle} \in \mathcal{O} \mathcal{K}_{* *}^{\langle R\rangle}} .
\end{aligned}
$$

If $\left|X_{R}\right|>1$ then

$$
\begin{aligned}
& X_{R}^{*}=\left\{x_{m_{* *}^{\left\langle R^{*}\right\rangle}}\right\}_{m_{* *}^{\left\langle R^{*}\right\rangle} \in \mathscr{M}_{* *}^{\left\langle R^{*}\right\rangle}} \\
& =\arg \max _{\substack{x_{m_{* *}^{\langle R\rangle}}^{\langle R\rangle} \\
m_{* *}^{\langle R\rangle} \in \mathscr{C M}_{* *}^{\langle R\rangle}}} \sum_{n_{* *}^{\langle R\rangle} \in \mathscr{C}_{* *}^{\langle R\rangle}} \sum_{k_{* *}^{\langle R\rangle} \in \mathscr{C}_{* *}^{\langle R\rangle}} a_{m_{* *}^{\langle R\rangle} n_{* *}^{\langle R\rangle} k_{* *}^{\langle R\rangle}} \\
& \subset X_{R} \subset X_{* *} \subset X_{*} \subset X \\
& \text { by } \mathscr{M}_{* *}^{\left\langle R^{*}\right\rangle} \subset \mathcal{M}_{* *}^{\langle R\rangle} \subset \mathscr{M}_{* *} \subset \mathscr{M}_{*} \text {, }
\end{aligned}
$$

otherwise, if $\left|X_{R}\right|=1$, then $X_{R}^{*}=X_{R}$. If $\left|Y_{R}\right|>1$ then

$$
Y_{R}^{*}=\left\{y_{n_{* *}^{\left\langle R^{*}\right\rangle}}\right\}_{n_{* *}^{\left\langle R^{*}\right\rangle} \in \mathscr{C}_{* *}^{\left\langle R^{*}\right\rangle}}
$$

$$
\begin{aligned}
\arg & \max _{\substack{y_{n_{* *}^{\langle R\rangle}}^{\langle R\rangle} \\
n_{* *}^{\langle R\rangle} \in \mathscr{N}_{* *}^{\langle R\rangle}}} \sum_{m_{* *}^{\langle R\rangle} \in \mathscr{M}_{* *}^{\langle R\rangle}} \sum_{k_{* *}^{\langle R\rangle} \in \mathscr{C}_{* *}^{\langle R\rangle}} b_{m_{* *}^{\langle R\rangle} n_{* *}^{\langle R\rangle} k_{* *}^{\langle R\rangle}} \\
& \subset Y_{R} \subset Y_{* *} \subset Y_{*} \subset Y \\
\text { by } \quad \mathscr{N}_{* *}^{\left\langle R^{*}\right\rangle} \subset \mathcal{O N} &
\end{aligned}
$$

otherwise, if $\left|Y_{R}\right|=1$, then $Y_{R}^{*}=Y_{R}$. If $\left|Z_{R}\right|>1$ then

$$
\begin{aligned}
& Z_{R}^{*}=\left\{z_{k_{* *}^{\left\langle R^{*}\right\rangle}}\right\}_{k_{* *}^{\left\langle R^{*}\right\rangle} \in \mathscr{C}_{* *}^{\left\langle R^{*}\right\rangle}}
\end{aligned}
$$

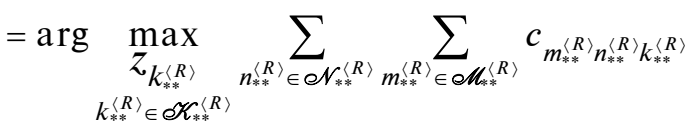

$$
\begin{aligned}
& \subset Z_{R} \subset Z_{* *} \subset Z_{*} \subset Z \\
& \text { by } \mathscr{K}_{* *}^{\left\langle R^{*}\right\rangle} \subset \mathscr{K}_{* *}^{\langle R\rangle} \subset \mathcal{e} \mathcal{K}_{* *} \subset \mathcal{O K} \text {, }
\end{aligned}
$$

otherwise, if $\left|Z_{R}\right|=1$, then $Z_{R}^{*}=Z_{R}$. Note that finding sets (29), (30), and (31) does not guarantee that

$$
\left\{X_{R}^{*} \times Y_{R}^{*} \times Z_{R}^{*}\right\} \cap R \neq \varnothing,
$$

where a case

$$
\left|\left\{X_{R}^{*} \times Y_{R}^{*} \times Z_{R}^{*}\right\} \cap R\right|=1
$$

is as ideal as the case $|R|=1$. Statement (32) is only assuredly true for one of the three cases:

1) when $\left|X_{R}\right|=1$ and $\left|Y_{R}\right|=1$;

2) when $\left|X_{R}\right|=1$ and $\left|Z_{R}\right|=1$;

3) when $\left|Y_{R}\right|=1$ and $\left|Z_{R}\right|=1$.

Hence, the refinement is done by processing the reduced game with payoff matrices (15), wherein primarily maximinimin subsets (16), (17), and (18) are found along with maximinimin payoffs (19), (20), and (21). The process of refining is continued to payoff aggregate maximizations if $|R| \neq 1$. However, what makes players come through such a process? Will the best efficient Nash equilibrium, straightforwardly returned by $|R|=1$ or by (33), be selected by the players, which act non-cooperatively, though? These questions are to be answered in the section right below.

Why players should non-cooperatively come at the best efficient Nash equilibrium returned by the developed approach refinement

The refinement by the approach developed for trimatrix games is counted perfectly finished when 
$|R|=1$ or (33) is true. If product (22) of the maximinimin subsets has responded perfectly, i. e. set (22) contains a single efficient equilibrium, then every player does not have any reason to use strategies from other situations (all the more if they are not equilibria). Surely, that single efficient equilibrium will be unprofitable/disadvantageous for one or two players, if there are at least two equilibria producing different payoffs. But if a player losing some at the single refined efficient equilibrium tries to improve one's payoff, then it will be hardly improved even for a few rounds of the game as the improvement needs that other players do not change their strategies. In other words, while at the Nash equilibrium a player cannot improve one's payoff by acting oneself, at the single refined efficient equilibrium it is unlikely for a player to improve one's payoff at least for a few rounds of the game [16, 22, 27, 28].

For instance, a trimatrix game with payoff $2 \times 2 \times 2$ matrices

$$
\begin{aligned}
& \mathbf{A}=\left[\left(\begin{array}{ll}
7 & 4 \\
5 & 5
\end{array}\right)\left(\begin{array}{ll}
6 & 2 \\
2 & 4
\end{array}\right)\right], \\
& \mathbf{B}=\left[\left(\begin{array}{ll}
7 & 6 \\
7 & 6
\end{array}\right)\left(\begin{array}{ll}
1 & 3 \\
4 & 5
\end{array}\right)\right], \\
& \mathbf{C}=\left[\left(\begin{array}{ll}
7 & 4 \\
2 & 8
\end{array}\right)\left(\begin{array}{ll}
5 & 2 \\
2 & 8
\end{array}\right)\right],
\end{aligned}
$$

being slightly modified matrices (10), has two efficient Nash equilibria $-e_{1}=\left\{x_{1}, y_{1}, z_{1}\right\}$ and $e_{2}=\left\{x_{2}, y_{2}, z_{2}\right\}$ producing the respective payoffs $\{7,7,7\}$ and $\{4,5,8\}$. Thus, here

$$
\begin{gathered}
E=\left\{e_{q}\right\}_{q=1}^{2} \subset X_{*} \times Y_{*} \times Z_{*} \\
=\left\{x_{1}, x_{2}\right\} \times\left\{y_{1}, y_{2}\right\} \times\left\{z_{1}, z_{2}\right\}=X \times Y \times Z .
\end{gathered}
$$

Maximinimin subsets (16), (17), and (18) are as follows:

$$
\begin{aligned}
X_{* *}= & \arg \max _{\left\{x_{1}, x_{2}\right\}}\{\min \{7,4,6,2\}, \min \{5,5,2,4\}\} \\
= & \arg \max _{\left\{x_{1}, x_{2}\right\}}\{2,2\}=\left\{x_{1}, x_{2}\right\}=X_{*}=X, \\
Y_{* *}= & \arg \max _{\left\{y_{1}, y_{2}\right\}}\{\min \{7,1,7,4\}, \min \{6,3,6,5\}\} \\
& =\arg \max _{\left\{y_{1}, y_{2}\right\}}\{1,3\}=\left\{y_{2}\right\} \subset Y_{*} \subset Y,
\end{aligned}
$$

$$
\begin{aligned}
Z_{* *} & =\arg \max _{\left\{z_{1}, z_{2}\right\}}\{\min \{7,4,2,8\}, \min \{5,2,2,8\}\} \\
& =\arg \max _{\left\{z_{1}, z_{2}\right\}}\{2,2\}=\left\{z_{1}, z_{2}\right\}=Z_{*}=Z
\end{aligned}
$$

whereupon the players are guaranteed to get payoffs not less than

$$
a_{* *}=2, b_{* *}=3, c_{* *}=2
$$

by (19)-(21). As

$$
\begin{aligned}
e_{2} & =\left\{x_{2}, y_{2}, z_{2}\right\} \in X_{*} \times Y_{*} \times Z_{*} \\
& =\left\{x_{1}, x_{2}\right\} \times\left\{y_{2}\right\} \times\left\{z_{1}, z_{2}\right\}
\end{aligned}
$$

is the single refined efficient equilibrium, then the refinement is perfectly finished here. The players aim at payoffs $\{4,5,8\}$. For the first and second players these payoffs are less than those 7 and 7 at $e_{1}=\left\{x_{1}, y_{1}, z_{1}\right\}$. But if they try to improve those 4 and 5, say, by changing both their strategies (to the first-indexed strategies), the payoffs will become $\{6,1,5\}$. Then the second player losing so much upon the "improvement" will likely attempt to change one's strategy. Meanwhile, the third player may think about to get at equilibrium $e_{1}=$ $=\left\{x_{1}, y_{1}, z_{1}\right\}$ and so on, this mess will go on. This is why the single refined efficient equilibrium included into the product of maximinimin subsets (35)-(37) is an attractive point for all the players. This situation can be called the metaequilibrium. The metaequilibrium in this case, where $|R|=1$, is "supported" by the maximinimin principle.

The similar reasoning stands for the case when $|R|>1$ but (33) is true. Having slightly modified matrices (34) to

$$
\begin{aligned}
& \mathbf{A}=\left[\left(\begin{array}{ll}
7 & 4 \\
5 & 5
\end{array}\right)\left(\begin{array}{ll}
6 & 2 \\
2 & 4
\end{array}\right)\right], \\
& \mathbf{B}=\left[\left(\begin{array}{ll}
7 & 6 \\
7 & 6
\end{array}\right)\left(\begin{array}{ll}
3 & 3 \\
4 & 5
\end{array}\right)\right], \\
& \mathbf{C}=\left[\left(\begin{array}{ll}
7 & 4 \\
2 & 8
\end{array}\right)\left(\begin{array}{ll}
5 & 2 \\
2 & 8
\end{array}\right)\right],
\end{aligned}
$$

we get a maximinimin subsets' product equal to the product of players' pure strategy sets, i. e.

$$
\begin{gathered}
E=R=\left\{\left\{x_{1}, y_{1}, z_{1}\right\},\left\{x_{2}, y_{2}, z_{2}\right\}\right\} \\
\subset X_{R} \times Y_{R} \times Z_{R}=X_{* *} \times Y_{* *} \times Z_{* *} \\
=X_{*} \times Y_{*} \times Z_{*}=X \times Y \times Z
\end{gathered}
$$


and the same payoff triplets are produced. Then the superoptimality rule by (29)-(31) is applied:

$$
\begin{gathered}
X_{R}^{*}=\arg \max _{\left\{x_{1}, x_{2}\right\}}\{7+4+6+2,5+5+2+4\} \\
=\arg \max _{\left\{x_{1}, x_{2}\right\}}\{19,16\}=\left\{x_{1}\right\}, \\
Y_{R}^{*}=\arg \max _{\left\{y_{1}, y_{2}\right\}}\{7+3+7+4,6+3+6+5\} \\
=\arg \max _{\left\{y_{1}, y_{2}\right\}}\{21,20\}=\left\{y_{1}\right\}, \\
Z_{R}^{*}=\arg \max _{\left\{z_{1}, z_{2}\right\}}\{7+4+2+8,5+2+2+8\} \\
=\arg \max _{\left\{z_{1}, z_{2}\right\}}\{21,17\}=\left\{z_{1}\right\},
\end{gathered}
$$

whence $e_{1}=\left\{x_{1}, y_{1}, z_{1}\right\}$ is the metaequilibrium.

\section{An algorithm of using the developed approach refinement in trimatrix games}

The developed approach refinement gives us one of the seven possible final results:

1. A single metaequilibrium is returned when $|R|=1$ being the perfect and fastest refinement result.

2. A single metaequilibrium is returned when $|R|>1$ and (33) is true being the perfect refinement result as well.

3. A fail of the refinement occurs when $|R|>1$ and (33) is false by

$$
\left\{X_{R}^{*} \times Y_{R}^{*} \times Z_{R}^{*}\right\} \cap R=\varnothing,
$$

that is the same as the fail of condition (32). Such a result is not treated totally negative if

$$
1<|R|<|E|
$$

implying that the uncertainty of equilibria has been nonetheless partially reduced. The total negative result is when $|R|=|E|$ by (43), that is the superoptimality rule does not hit an equilibrium by the maximinimin hit the whole set of the equilibria.

4. A few metaequilibria are returned when $|R|>1$ and (33) is false by

$$
\left|\left\{X_{R}^{*} \times Y_{R}^{*} \times Z_{R}^{*}\right\} \cap R\right|>1 .
$$

Such a result is treated positive if

$$
1<\left|\left\{X_{R}^{*} \times Y_{R}^{*} \times Z_{R}^{*}\right\} \cap R\right|<|E| .
$$

However, the result will be treated total negative (factually, a fail of the refinement) when

$$
\left|\left\{X_{R}^{*} \times Y_{R}^{*} \times Z_{R}^{*}\right\} \cap R\right|=|E|,
$$

that is both the maximinimin and superoptimality work for nothing, hitting the whole set of the equilibria and making thus no uncertainty reduction (those metaequilibria are the same as all those efficient equilibria).

5. A single metaequilibrium is returned when $R=\varnothing$ but

$$
\left|\left\{\widehat{X}_{*} \times \widehat{Y}_{*} \times \hat{Z}_{*}\right\} \cap E\right|=1 .
$$

Although maximinimin misses all the equilibria, the superoptimality rule perfectly hits the single metaequilibrium.

6. The refinement totally fails when $R=\varnothing$ and

$$
\left\{\widehat{X}_{*} \times \widehat{Y}_{*} \times \widehat{Z}_{*}\right\} \cap E=\varnothing .
$$

Here both the maximinimin and superoptimality do not work, missing all the equilibria.

7. A few metaequilibria are returned when $R=\varnothing$ but

$$
\left|\left\{\widehat{X}_{*} \times \widehat{Y}_{*} \times \widehat{Z}_{*}\right\} \cap E\right|>1 .
$$

Such a result is treated positive if

$$
1<\left|\left\{\widehat{X}_{*} \times \widehat{Y}_{*} \times \widehat{Z}_{*}\right\} \cap E\right|<|E| .
$$

However, the result will be treated total negative (factually, a fail of the refinement) when

$$
\left|\left\{\widehat{X}_{*} \times \widehat{Y}_{*} \times \hat{Z}_{*}\right\} \cap E\right|=|E|,
$$

that is the superoptimality rules works for nothing, hitting the whole set of the equilibria and making thus no uncertainty reduction (those metaequilibria are the same as all those efficient equilibria).

The developed approach refinement in trimatrix games should be used algorithmically (Fig. 2):

1. Find maximinimin subsets $(16)-(18)$ over payoff matrices (15).

2. Return a single metaequilibrium if $|R|=1$, i. e. the product of maximinimin subsets $(16)-(18)$ contains the single equilibrium.

3. If $|R|>1$ then maximize the respective players' payoffs over subsets (28), and find those of subsets (29)-(31) for whom the corresponding subsets in (28) contain more than one strategy. Eventually, return the resulting metaequilibrium or metaequilibria in set 


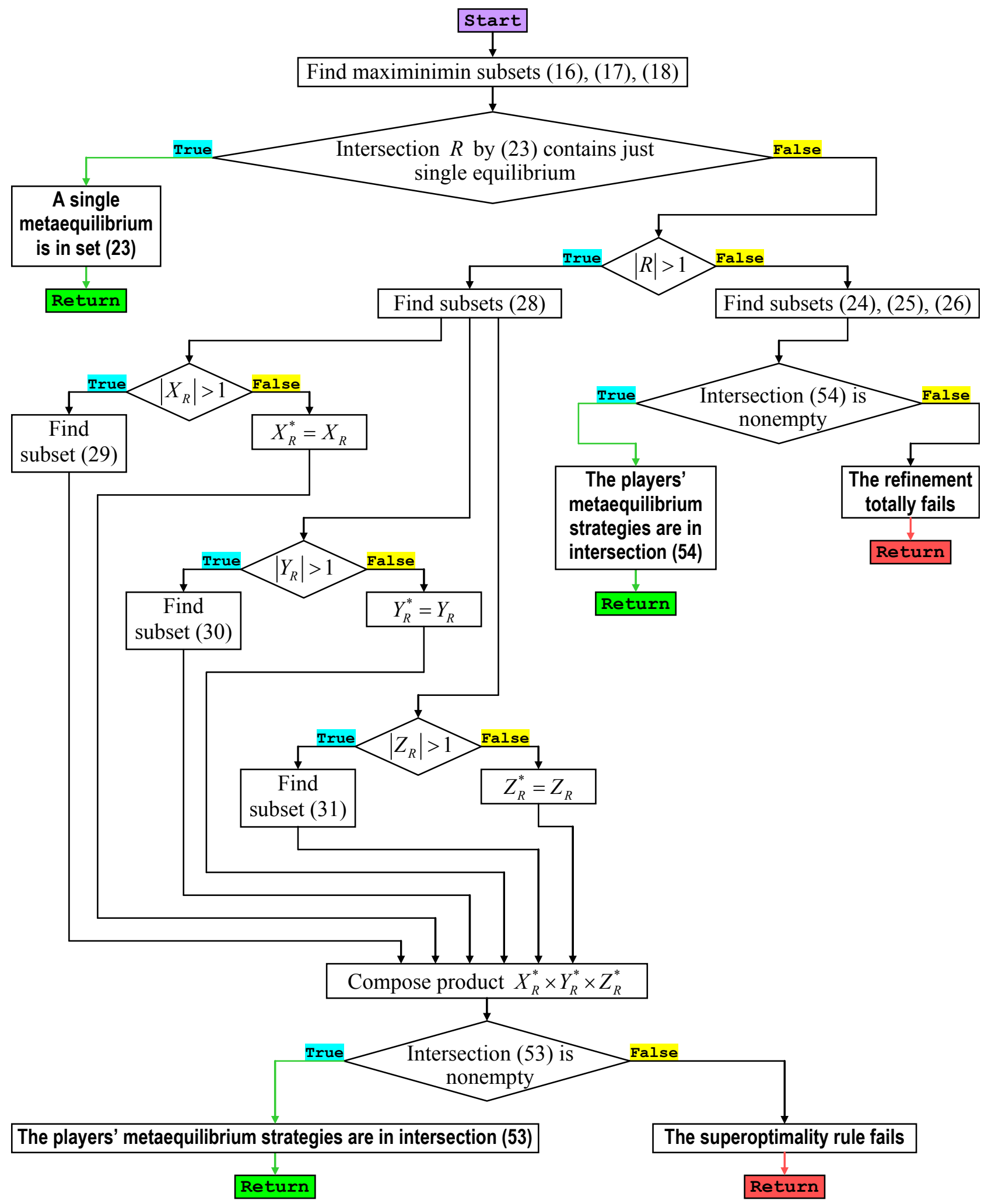

Fig. 2. An algorithmic generalized scheme for the Nash equilibria refinement in trimatrix games 


$$
\left\{X_{R}^{*} \times Y_{R}^{*} \times Z_{R}^{*}\right\} \cap R,
$$

if set (53) is not empty.

4. Otherwise, if $R=\varnothing$ then find subsets (24)-(26) that maximize the respective players' payoffs over subsets (5). Eventually, return the resulting set

$$
\left\{\widehat{X}_{*} \times \widehat{Y}_{*} \times \hat{Z}_{*}\right\} \cap E,
$$

whether containing metaequilibria or not.

Obviously, the algorithm cannot guarantee that a single efficient equilibrium will remain after the refinement. Nevertheless, its recommendations are based on pure logic and reasonability of aiming at the guaranteed payoffs, whether at a metaequilibrium or not $[1,10,11,16,29,30]$. An example is a trimatrix game with payoff $7 \times 4 \times 5$ matrices (Fig. 3), whose set of efficient equilibria

$$
\begin{gathered}
E=\left\{e_{q}\right\}_{q=1}^{5}=\left\{\left\{x_{2}, y_{4}, z_{1}\right\},\left\{x_{2}, y_{4}, z_{3}\right\},\right. \\
\left.\left\{x_{4}, y_{1}, z_{4}\right\},\left\{x_{4}, y_{2}, z_{3}\right\},\left\{x_{5}, y_{2}, z_{4}\right\}\right\}
\end{gathered}
$$

produces the respective payoffs

$\{9,7,8\},\{7,9,8\},\{9,8,7\},\{9,6,9\},\{8,8,9\}$.

Product (22)

$$
\begin{gathered}
L=X_{* *} \times Y_{* *} \times Z_{* *} \\
=\left\{x_{2}, x_{4}, x_{5}\right\} \times\left\{y_{1}, y_{2}, y_{4}\right\} \times\left\{z_{1}, z_{4}\right\}
\end{gathered}
$$

of maximinimin subsets (16)-(18) contains three equilibria:
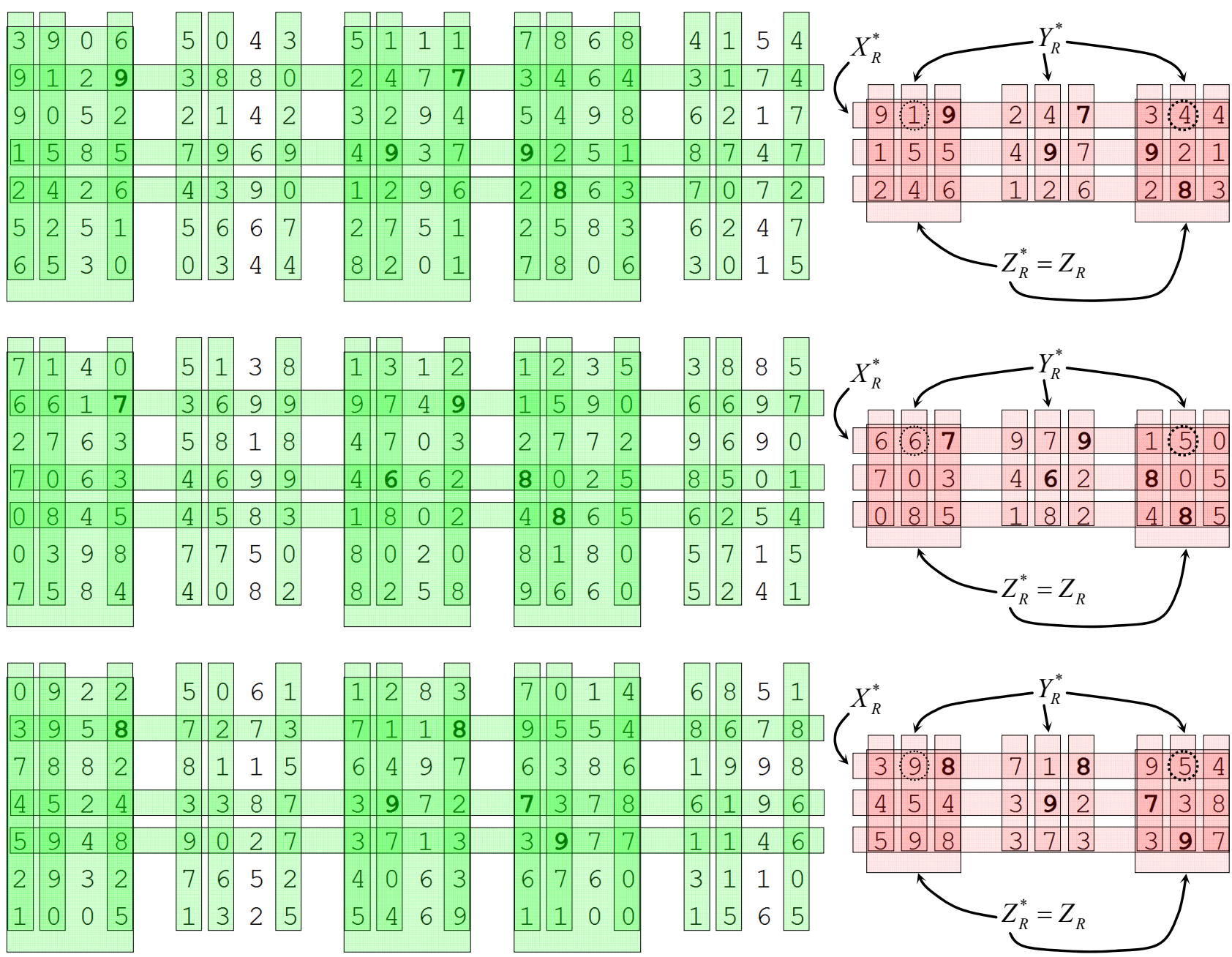

Fig. 3. Screenshots of payoff matrices of a trimatrix $7 \times 4 \times 5$ game showing strategies of sets (5) as stripes corresponding to efficient equilibria highlighted bold, and, after having reduced the game, strategies of maximinimin subsets (16)-(18) as stripes (to the right); sets $X_{R}^{*}, Y_{R}^{*}$, and $Z_{R}^{*}$ are arrowed; two payoff triplets produced by situations of product $X_{R}^{*} \times Y_{R}^{*} \times Z_{R}^{*}$ are circle-dotted 


$$
\begin{gathered}
R=L \cap E=\left\{\left\{e_{1}, e_{3}, e_{5}\right\}\right\} \\
=\left\{\left\{x_{2}, y_{4}, z_{1}\right\},\left\{x_{4}, y_{1}, z_{4}\right\},\left\{x_{5}, y_{2}, z_{4}\right\}\right\} .
\end{gathered}
$$

But the refinement is finished at the stage of set (58) as the superoptimality rule by (29)-(31) gives the empty set (53):

$$
\begin{gathered}
X_{R}^{*}=\arg \max _{\left\{x_{2}, x_{4}, x_{5}\right\}}\{9+1+9+3+4+4, \\
1+5+5+9+2+1,2+4+6+2+8+3\} \\
=\arg \max _{\left\{x_{2}, x_{4}, x_{5}\right\}}\{30,23,25\}=\left\{x_{2}\right\}, \\
Y_{R}^{*}=\arg \max _{\left\{y_{1}, y_{2}, y_{4}\right\}}\{6+7+0+1+8+4, \\
6+0+8+5+0+8,7+3+5+0+5+5\} \\
=\arg \max _{\left\{y_{1}, y_{2}, y_{4}\right\}}\{26,27,25\}=\left\{y_{2}\right\}, \\
Z_{R}^{*}=\arg \max _{\left\{z_{1}, z_{4}\right\}}\{3+9+8+4+5+4+5+9+8, \\
9+5+4+7+3+8+3+9+7\} \\
=\arg \max _{\left\{z_{1}, z_{4}\right\}}\{55,55\}=\left\{z_{1}, z_{4}\right\},
\end{gathered}
$$

whence

$$
\begin{gathered}
\left\{X_{R}^{*} \times Y_{R}^{*} \times Z_{R}^{*}\right\} \cap R \\
=\left\{\left\{x_{2}, y_{2}, z_{1}\right\},\left\{x_{2}, y_{2}, z_{4}\right\}\right\} \cap\left\{\left\{x_{2}, y_{4}, z_{1}\right\},\right. \\
\left.\left\{x_{4}, y_{1}, z_{4}\right\},\left\{x_{5}, y_{2}, z_{4}\right\}\right\}=\varnothing .
\end{gathered}
$$

The recommendation of strategies (59)-(61) does not mean that the players must choose between two situations $\left\{x_{2}, y_{2}, z_{1}\right\}$ and $\left\{x_{2}, y_{2}, z_{4}\right\}$ producing too disappointing payoff triplets (especially for the first and second players) $\{1,6,9\}$ and $\{4,5,5\}$. It just means that the uncertainty of the equilibria has been partially reduced from five equilibria within set (55) down to three equilibria within set $(58)$, i. e. set (55) has been partially refined into set (58).

In another trimatrix game example, with payoff $3 \times 2 \times 3$ matrices

$$
\begin{aligned}
& \mathbf{A}=\left[\left(\begin{array}{ll}
1 & 5 \\
4 & 5 \\
8 & 5
\end{array}\right)\left(\begin{array}{ll}
0 & 9 \\
2 & 9 \\
5 & 5
\end{array}\right)\left(\begin{array}{ll}
5 & 3 \\
9 & 1 \\
7 & 7
\end{array}\right)\right], \\
& \mathbf{B}=\left[\left(\begin{array}{ll}
4 & 4 \\
6 & 6 \\
9 & 5
\end{array}\right)\left(\begin{array}{ll}
3 & 9 \\
5 & 1 \\
3 & 1
\end{array}\right)\left(\begin{array}{ll}
7 & 3 \\
6 & 6 \\
6 & 2
\end{array}\right)\right],
\end{aligned}
$$

$$
\mathbf{C}=\left[\left(\begin{array}{ll}
3 & 9 \\
5 & 8 \\
4 & 5
\end{array}\right)\left(\begin{array}{ll}
2 & 0 \\
5 & 7 \\
1 & 7
\end{array}\right)\left(\begin{array}{ll}
8 & 7 \\
5 & 3 \\
1 & 0
\end{array}\right)\right],
$$

there are four efficient equilibria:

$$
\begin{gathered}
E=\left\{e_{q}\right\}_{q=1}^{4}=\left\{\left\{x_{1}, y_{2}, z_{1}\right\},\left\{x_{2}, y_{1}, z_{3}\right\},\right. \\
\left.\left\{x_{2}, y_{2}, z_{1}\right\},\left\{x_{3}, y_{1}, z_{1}\right\}\right\}
\end{gathered}
$$

and the respective payoffs

$$
\{5,4,9\},\{9,6,5\},\{5,6,8\},\{8,9,4\}
$$

are produced by situations in set (64). Having reduced this game to $3 \times 2 \times 2$ game, where

$$
\begin{gathered}
\mathbf{A}_{*}=\left[\left(\begin{array}{ll}
1 & 5 \\
4 & 5 \\
8 & 5
\end{array}\right)\left(\begin{array}{ll}
5 & 3 \\
9 & 1 \\
7 & 7
\end{array}\right)\right], \\
\mathbf{B}_{*}=\left[\left(\begin{array}{ll}
4 & 4 \\
6 & 6 \\
9 & 5
\end{array}\right)\left(\begin{array}{ll}
7 & 3 \\
6 & 6 \\
6 & 2
\end{array}\right)\right],
\end{gathered}
$$

$$
\mathbf{C}_{*}=\left[\left(\begin{array}{ll}
3 & 9 \\
5 & 8 \\
4 & 5
\end{array}\right)\left(\begin{array}{ll}
8 & 7 \\
5 & 3 \\
1 & 0
\end{array}\right)\right],
$$

we obtain a single maximinimin situation that happens to be an equilibrium:

$$
\begin{gathered}
L=X_{* *} \times Y_{* *} \times Z_{* *} \\
=\left\{x_{3}\right\} \times\left\{y_{1}\right\} \times\left\{z_{1}\right\}=\left\{\left\{x_{3}, y_{1}, z_{1}\right\}\right\}=\left\{e_{4}\right\},
\end{gathered}
$$

i. e. $|R|=1$. This is an example of the totally successful/perfect refinement. Here, at single metaequilibrium (67), the third player may be apparently not satisfied with the metaequilibrium payoff triplet $\{8,9,4\}$. But if the third player attempts to change one's strategy, then the payoff will be equal to 1 - in both games with matrices (63) and (66) as the other players have no reasons to leave their maximinimin strategies.

\section{Discussion of advantages, disadvantages, and issues}

The exemplified games are rather close to ultimate illustrative cases where payoffs appear illogically scattered [19, 22, 24, 31]. In more real examples, the developed approach works fine. It is con- 

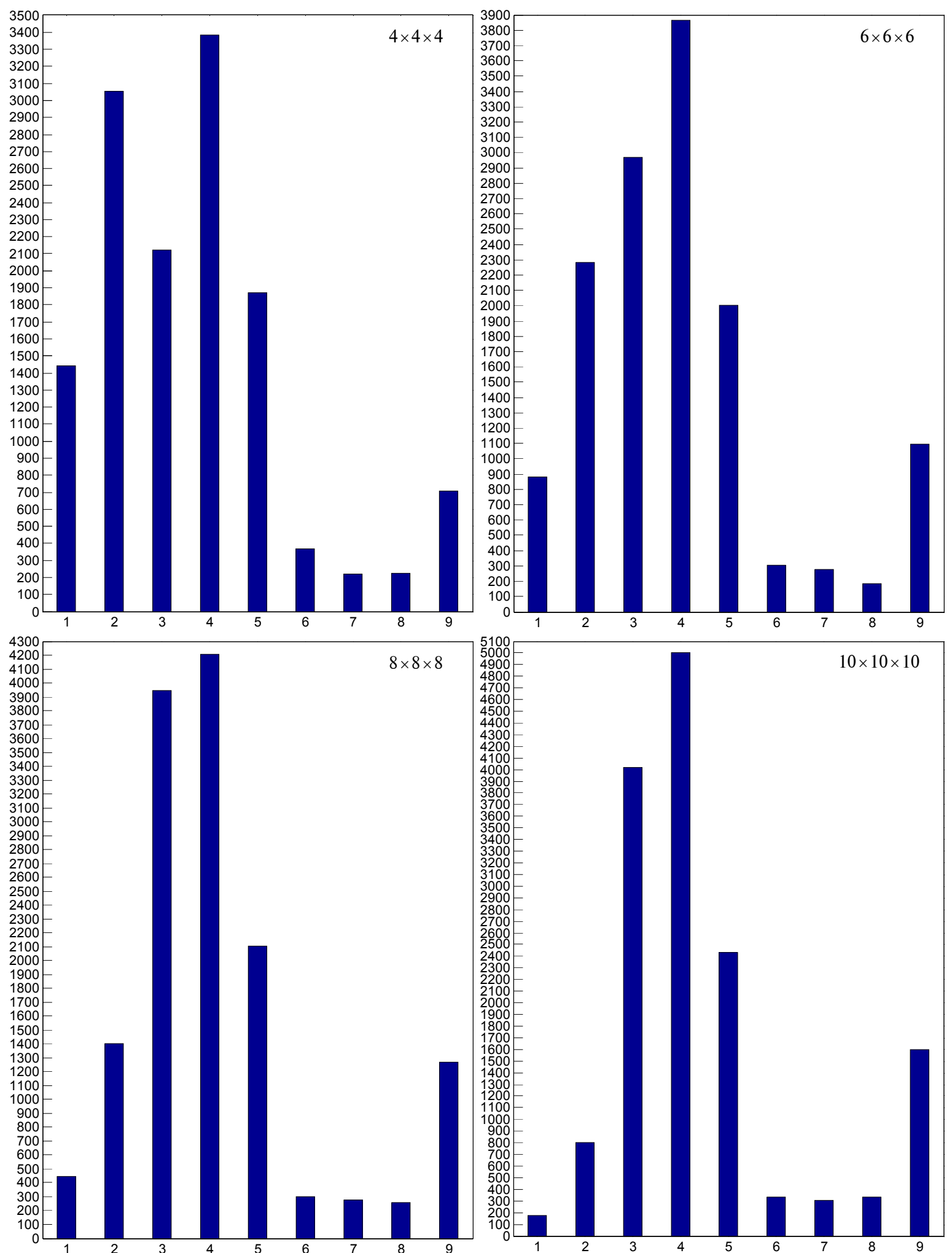

Fig. 4. Numbers characterizing the refinement for 10,000 game simulations with (68) by $C=40: 1-$ a number of games without Nash equilibria; 2 - a single equilibrium; 3 - a single efficient equilibrium; $4-Q>1 ; 5-|R|=1 ; 6-|R|>1$ and either (33) or (45) is true (at least a metaequilibrium is returned by the superoptimality rule); $7-R=\varnothing$ and either (48) or (50) is true (at least a metaequilibrium is returned by the superoptimality rule); $8-|R|>1$ but (43) is true (the superoptimality rule fails); $9-R=\varnothing$ and (49) is true (the refinement totally fails) 
firmed by series of trimatrix game simulations, where entries of payoff matrices (1) are formed on a base of pseudorandom numbers drawn from the standard uniform distribution on the open interval $(0 ; 1)$. Before a simulation, an $M \times N \times K$ payoff matrix is taken equal to

$$
\Psi(10 \cdot \Theta(M, N, K))+C
$$

by a function $\Theta(M, N, K)$ returning a pseudorandom $M \times N \times K$ matrix drawn from the standard uniform distribution on the open interval $(0 ; 1)$ and a function $\Psi(\xi)$ returning the integer part of number $\xi$, where $C$ is a positive constant taken such that the payoffs would not appear illogically scattered (see a generator of examples in [32]). A few typical simulation results are shown in Fig. 4. They allow concluding on that whereas the refinement is needed in about between $33 \%$ and $65 \%$ of trimatrix games where players possess between 4 to 12 pure strategies (this rate increases as the game size increases), it is perfectly accomplished to a single metaequilibrium in roughly between $46 \%$ and $52 \%$ of those cases (this rate decreases as the game size increases), using maximinimin only, without the superoptimality rule.

A merit of the said percentage rate is supplemented with ratios among those bars in Fig. 4. As the game size increases, additionally to the mentioned above, the following features are observed: decreases.

1. A number of games without Nash equilibria

2. A number of games having a single Nash equilibrium decreases.

3. A number of games having a single efficient equilibrium (while there are more than a one Nash equilibrium) increases.

4. Despite the increment of the single efficient equilibrium, a number of games having multiple efficient equilibria increases also. Such multiplicity is pretty conditional for games of smaller sizes as they have only a few equilibria. For example, a majority of the simulated $4 \times 4 \times 4$ games with multiple efficient equilibria has had only two equilibria. Bigger size games have more real "multiplicity" of equilibria, where a rate of cases with three and more equilibria increases.

5. A number of cases when $|R|=1$ (a single metaequilibrium) increases but it goes slower than the increment of multiple efficient equilibria, and thus the percentage rate of the perfectly accomplished refinement (to a single metaequilibrium using maximinimin only, without the superoptimality rule) slowly decreases (as it has been mentioned before referring to Fig. 4).

6. A number of cases when both the maximinimin and superoptimality work fine is a few times lesser than the perfect refinement accomplishment, but this number slightly exceeds a number of cases when $R=\varnothing$ and at least a metaequilibrium is returned by the superoptimality rule. Besides, it is about to exceed a number of cases when $|R|>1$ but the superoptimality rule fails.

7. Despite the increment of the perfect refinement accomplishment, a number of total fails of the refinement, when $R=\varnothing$ and (49) is true, increases. It is plausibly explained with that the increasing number of games with multiple efficient equilibria increases chances of nonrefinability.

Thus, advantages of the developed approach are obvious. The maximinimin principle works fine and the superoptimality rule stands like a backup plan, although its failure is not excluded. Narrowing a set of multiple efficient equilibria, i. e. removing the uncertainty of equilibria partially by achieving one of conditions (44), (46), (51), is another advantage. Not going into mixed strategies is a plain merit for benefits of fast practical realization, especially of games with a few rounds [27, 33].

If payoffs are illogically scattered then the metaequilibrium may be a way disadvantageous for one or two players. This is a disadvantage common for the known refinement concepts. Typical examples to this are games with payoff matrices (34) and (63).

An unsolved issue concerns games with identical/symmetric payoffs having nonrefinable equilibria $[7,8,20,23,34,36]$. An exemplary class of such games was described in the section with formulae (11)-(14). Both mirror-like symmetry and cyclic symmetry make equilibria principally nonrefinable, so the unsolved-ness here should be rather treated as nonrefinability-ness.

\section{Conclusions}

The suggested Nash equilibria refinement in trimatrix games has been developed on a base of expanding the refinement approach for bimatrix games. Exploiting the maximin, expanded to the maximinimin principle, and superoptimality using now double-summing, the main work for the refinement is off the maximinimin principle. The superoptimality rule is involved if maximinimin fails to produce just a single refined equilibrium now- 
called metaequilibrium. The aggregate efficiency of such refinement, which is exemplarily visualized in Fig. 4, seems satisfactory.

Theoretically, the contribution to the equilibria refinement game theory field by the developed approach still can be advanced for cases when the uncertainty of equilibria is removed only partially, that is when one of conditions (44), (46), (51) is achieved. In the case when the approach totally fails, that is when $R=\varnothing$ and (49) is true, the advancement (if this word is appropriate here) is unlikely. Then, however, maximinimin and superoptimality still can be (additionally) applied over some subsets of subsets in (16)-(18), (24)-(26), (29)-(31). If it does not help, then a method of approximate Nash equilibrium situations with possible concessions can be invoked [21, 32]. A future equilibria refinement theory for finite noncooperative games, mentioned in [7], will use the smallest possible concessions to refine equilibria nonrefinable by the known concepts.

\section{References}

[1] J.C. Harsanyi and R. Selten, A General Theory of Equilibrium Selection in Games. Cambridge, UK: The MIT Press, 1988,365 p.

[2] R.B. Myerson, "Refinements of the Nash equilibrium concept", Int. J. Game Theory, vol. 7, iss. 2, pp. 73-80, 1978. doi: $10.1007 / \mathrm{BF} 01753236$

[3] S. Belhaiza et al., "On proper refinement of Nash equilibria for bimatrix games", Automatica, vol. 48, iss. 2, pp. 297-303, 2012. doi: 10.1016/j.automatica.2011.07.013

[4] C. Meroni and C. Pimienta, "The structure of Nash equilibria in Poisson games", J. Economic Theory, vol. 169, pp. 128-144, 2017. doi: $10.1016 /$ j.jet.2017.02.003

[5] D. Fudenberg and J. Tirole, "Perfect Bayesian equilibrium and sequential equilibrium", J. Economic Theory, vol. 53, iss. 2, pp. 236-260, 1991. doi: 10.1016/0022-0531(91)90155-W

[6] D. Gerardi and R.B. Myerson, "Sequential equilibria in Bayesian games with communication", Games and Economic Behavior, vol. 60, iss. 1, pp. 104-134, 2007. doi: 10.1016/j.geb.2006.09.006

[7] V.V. Romanuke, "Pure strategy Nash equilibria refinement in bimatrix games by using domination efficiency along with maximin and the superoptimality rule", KPI Sci News, no. 3, pp. 42-52, 2018. doi: 10.20535/1810-0546.2018.3.12853

[8] M. Fey, "Symmetric games with only asymmetric equilibria", Games and Economic Behavior, vol. 75, iss. 1, pp. 424-427, 2012. doi: 10.1016/j.geb.2011.09.008

[9] G. Nöldeke and J. Peña, "The symmetric equilibria of symmetric voter participation games with complete information”, $G a-$ mes and Economic Behavior, vol. 99, pp. 71-81, 2016. doi: 10.1016/j.geb.2016.06.016

[10] W. Leinfellner and E. Köhler, Game Theory, Experience, Rationality. Foundations of Social Sciences, Economics and Ethics in Honor of John C. Harsanyi. Netherlands: Springer, 1998, 461 p. doi: 10.1007/978-94-017-1654-3

[11] N.N. Vorob'yov, Game Theory Fundamentals. Noncooperative Games. Moscow, SU: Nauka, 1984, 496 p.

[12] V.V. Romanuke, "Determining and applying the set of superoptimal pure strategies in some antagonistic games with nonempty set of saddle points in pure strategies", Visnyk of Zaporizhzhya National University. Physical and Mathematical Sciences, no. 2, pp. 120-125, 2010.

[13] V.V. Romanuke, "Superoptimal mixed strategies in antagonistic games as the advantaged subset of the optimal mixed strategies set”, Bulletin of Donetsk National University. Series A. Natural Sciences, no. 2, pp. 289-298, 2010.

[14] R. Selten, "Reexamination of the perfectness concept for equilibrium points in extensive games", Int. J. Game Theory, vol. 4, iss. 1, pp. 25-55, 1975. doi: 10.1007/BF01766400

[15] V.V. Romanuke, "Pure strategies Pareto efficient situations versus pure strategies Nash equilibrium situations by their stochastically constrained payoffs in dyadic game modeling of resources rational usage with alternative choice of action", Herald of Khmelnytskyi National University. Technical Sciences, no. 6, pp. 140-143, 2014.

[16] T. Kumano, "Nash implementation of constrained efficient stable matchings under weak priorities", Games and Economic Behavior, vol. 104, pp. 230-240, 2017. doi: 10.1016/j.geb.2017.04.003

[17] V. Scalzo, "Pareto efficient Nash equilibria in discontinuous games", Economics Letters, vol. 107, iss. 3, pp. 364-365, 2010. doi: 10.1016/j.econlet.2010.03.010

[18] J.R. Marden, "Selecting efficient correlated equilibria through distributed learning", Games and Economic Behavior, vol. 106, pp. 114-133, 2017. doi: 10.1016/j.geb.2017.09.007

[19] B.S.R. Pradelski and H. Peyton Young, "Learning efficient Nash equilibria in distributed systems", Games and Economic Behavior, vol. 75, iss. 2, pp. 882-897, 2012. doi: 10.1016/j.geb.2012.02.017

[20] S. Rachmilevitch, "Approximate equilibria in strongly symmetric games", J. Math. Economics, vol. 66, pp. 52-57, 2016. doi: 10.1016/j.jmateco.2016.07.003 
[21] V.V. Romanuke, "Approximate equilibrium situations with possible concessions in finite noncooperative game by sampling irregularly fundamental simplexes as sets of players' mixed strategies”, J. Uncertain Systems, vol. 10, no. 4, pp. 269-281, 2016.

[22] V.V. Romanuke, "Environment guard model as dyadic three-person game with the generalized fine for the reservoir pollution”, Ecological Safety and Nature Management, iss. 6, pp. 77-94, 2010.

[23] E. Boros et al., "Nash-solvable two-person symmetric cycle game forms", Discrete Appl. Math., vol. 159, iss. 15, pp. 14611487, 2011. doi: 10.1016/j.dam.2011.05.011

[24] P. Bouyer et al., "Nash equilibria in symmetric graph games with partial observation", Inform. Comput., vol. 254, p. 2, pp. 238-258, 2017. https://doi.org/10.1016/j.ic.2016.10.010

[25] V.V. Romanuke, "Minimaximax approach for finding optimal decisions' subset regarding changes of the loss function", Bulletin of V. Karazin Kharkiv National University. Ser. Mathematical Modelling. Information Technology. Automated Control Systems, iss. 33, pp. 81-89, 2017.

[26] V.V. Romanuke, "Finding an optimal decisions' subset by minimaximax regret criterion regarding instability of the decision function”, Naukovi Visti NTUU KPI, no. 5, pp. 35-40, 2017. doi: 10.20535/1810-0546.2017.5.105535

[27] V.V. Romanuke, "Formulation of an optimality principle in the elementary antagonistic game without saddle point by incomplete realization of optimal mixed strategies", Herald of Khmelnytskyi National University. Technical sciences, vol. 2, no. 2, pp. 218-222, 2007.

[28] P. Barelli and J. Duggan, "Purification of Bayes Nash equilibrium with correlated types and interdependent payoffs", Games and Economic Behavior, vol. 94, pp. 1-14, 2015. doi: 10.1016/j.geb.2015.08.005

[29] W. Grauberger and A. Kimms, "Computing approximate Nash equilibria in general network revenue management games", Eur. J. Operational Res., vol. 237, iss. 3, pp. 1008-1020, 2014. doi: 10.1016/j.ejor.2014.02.045

[30] P. Prokopovych and N. C. Yannelis, "On the existence of mixed strategy Nash equilibria", J. Math. Economics, vol. 52, pp. 87-97, 2014. doi: 10.1016/j.jmateco.2014.04.002

[31] M. Bravo and P. Mertikopoulos, "On the robustness of learning in games with stochastically perturbed payoff observations", Games and Economic Behavior, vol. 103, pp. 41-66, 2017. doi: 10.1016/j.geb.2016.06.004

[32] V.V. Romanuke, "Sampling individually fundamental simplexes as sets of players' mixed strategies in finite noncooperative game for applicable approximate Nash equilibrium situations with possible concessions", J. Inform. Organiz. Sci., vol. 40, no. 1, pp. 105-143, 2016

[33] V.V. Romanuke, "The tactics of the pure strategies selecting as a theoretic groundwork for investigating the efficiency of diverse ways of the optimal mixed strategies realization", Naukovi Visti NTUU KPI, no. 3, pp. 61-68, 2008

[34] C. Daskalakis et al., "A note on approximate Nash equilibria”, Theoretical Computer Sci., vol. 410, iss. 17, pp. 1581-1588, 2009. doi: $10.1016 /$ j.tcs.2008.12.031

[35] C. Daskalakis and C.H. Papadimitriou, "Approximate Nash equilibria in anonymous games”, J. Economic Theory, vol. 156, pp. 207-245, 2015. doi: 10.1016/j.jet.2014.02.002

\section{В.В. Романюк}

\section{УДОСКОНАЛЕННЯ ЕФЕКТИВНИХ РІВНОВАГ НЕША В ЧИСТИХ СТРАТЕГІЯХ З АЦИКЛІЧНО-АСИМЕТРИЧНИМИ ВИГРА- ШАМИ У ТРИМАТРИЧНИХ ІГРАХ ЗА МАКСИМІНІМІНОМ ТА НАДОПТИМАЛЬНІСТЮ}

Проблематика. Проблема вибору між ефективними рівновагами Неша вирішується завдяки їх удосконаленню. Існуючі підходи до такого вдосконалення не гарантують, що удосконалена ефективна рівновага Неша буде єдиною. Проте новий підхід до вдосконалення ефрективних рівноваг Неша в чистих стратегіях у біматричних іграх, запропонований раніше, використовує правило максиміну і надоптимальності, які, принаймні частково, усувають невизначеність рівноваг.

Мета дослідження. Мета статті - розвинути цей підхід для біматричних ігор, поширивши його на триматричні ігри для якомога кращого удосконалення ефективних рівноваг Неша.

Методика реалізації. Пропонується удосконалення ефективних рівноваг Неша для триматричних ігор, яке засноване на поширенні підходу до такого вдосконалення для біматричних ігор із використанням максимініміну і надоптимальності. Розглядаються тільки ігри з ациклічно-асиметричними трійками платежів.

Результати дослідження. Серії імітацій триматричних ігор дають змогу зробити висновок про те, що в той час як удосконалення потрібне в приблизно між 33 і 65 \% триматричних ігор, де гравці мають від 4 до 12 чистих стратегій (цей показник збільшується в міру збільшення розміру гри), воно повністю виконується у вигляді єдиної метарівноваги у приблизно між 46 і $52 \%$ цих випадків (цей показник зменшується зі збільшенням розміру гри), з використанням тільки максимініміну, без правила надоптимальності. Використовуючи максимін, поширений до принципу максимініміну, і надоптимальність, що використовує тепер подвійне підсумовування, основну роботу з удосконалення виконує принцип максимініміну.

Висновки. Алгоритм удосконалення за розробленим підходом у триматричних іграх дуже простий. Він складається з чотирьох узагальнених елементів. Хоча повний провал удосконалення не виключається, сукупна ефективність усунення невизначеності рівноваг за принципом максимініміну і правилом надоптимальності є задовільною.

Ключові слова: триматрична гра; ефрективні рівноваги Неша; удосконалення; максимінімін; правило надоптимальності. 


\section{В.В. Романюк}

\section{УСОВЕРШЕНСТВОВАНИЕ ЭФФЕКТИВНЫХ РАВНОВЕСИЙ НЕША В ЧИСТЫХ СТРАТЕГИЯХ С АЦИКЛИЧНО-АСИММЕТ-} РИЧНЫМИ ВЫИГРЫШАМИ В ТРИМАТРИЧНЫХ ИГРАХ ПО МАКСИМИНИМИНУ И СВЕРХОПТИМАЛЬНОСТИ

Проблематика. Проблема выбора между эффективными равновесиями Нэша решается путем их усовершенствования. Существующие подходы к такому усовершенствованию не гарантируют, что усовершенствованное эффективное равновесие Нэша будет единственным. Тем не менее новый подход к усовершенствованию эффективных равновесий Нэша в чистых стратегиях в биматричных играх, предложенный прежде, использует правило максимина и сверхоптимальности, которые, по крайней мере частично, устраняют неопределенность равновесий.

Цель исследования. Цель статьи - развить этот подход для биматричных игр, распространяя его на триматричные игры для как можно лучшего усовершенствования эффрективных равновесий Нэша.

Методика реализации. Предлагается усовершенствование эффективных равновесий Неша для триматричных игр, которое основано на распространении подхода к такому усовершенствованию для биматричных игр с использованием максиминимина и сверхоптимальности. Рассматриваются только игры с ациклично-асимметричными тройками платежей.

Результаты исследования. Серии имитаций триматричных игр позволяют заключить то, что в то время как усовершенствование требуется в примерно между 33 и 65 \% триматричных игр, где игроки имеют от 4 до 12 чистых стратегий (этот показатель увеличивается по мере увеличения размера игры), оно полностью выполняется в виде единственного метаравновесия в примерно между 46 и 52 \% этих случаев (этот показатель уменьшается с увеличением размера игры), с использованием только максиминимина, без правила сверхоптимальности. Используя максимин, распространенный до принципа максиминимина, и сверхоптимальность, использующую теперь двойное суммирование, основную работу по усовершенствованию выполняет принцип максиминимина.

Выводы. Алгоритм усовершенствования по разработанному подходу в триматричных играх очень прост. Он состоит из четырех обобщенных элементов. Хотя полный провал усовершенствования не исключается, совокупная эффрективность устранения неопределенности равновесий по принципу максиминимина и правилу сверхоптимальности представляется удовлетворительной.

Ключевые слова: триматричная игра; эффективные равновесия Неша; усовершенствование; максиминимин; правило сверхоптимальности.

Рекомендована Радою

факультету прикладної математики

КПІ ім. Ігоря Сікорського
Надійшла до редакції 22 травня 2018 року

Прийнята до публікації 6 вересня 2018 року 